Scientia Militaria vol 40, no 3, 2012, pp.250-279. doi: 10.5787/40-3-1035

\title{
The First South African Armoured Battle in Italy during the Second World War: The Battle of Celleno - 10 June 1944
}

Evert Kleynhans •

\begin{abstract}
The formation of 6 South African Armoured Division (6 SA Armd Div), during February 1943, afforded the Union Defence Force (UDF) the chance to expand its military capabilities to that of armoured warfare. An armoured division further offered South Africa the opportunity to equip the UDF with modern fighting equipment and to master the art of combined warfare. Actual deployment in Italy differed vastly from the training which the division received in North Africa, for Italy was arguably, largely "untankable". The Division's first battle occurred at Celleno, on 10 June 1944, where it was able to "prove" itself by securing its first victory. As far as secondary sources are concerned, the Battle of Celleno is only superficially covered. Primary sources are however abundant, thus adding to the rich history which is available on the Division. This article analyses the Battle of Celleno, fought by 11 SA Armoured Brigade, in the context of the notion of "first battles". Emphasis will be placed on the training received prior to deployment, the Battle of Celleno, the lessons that were learned by the division at Celleno, and the way these influenced future operations in Italy. The Division's combined-arms approach is also
\end{abstract}

- $\quad$ Evert Kleynhans, BMil Hons (Stell), is a candidate in the MMil Military History programme, Department of Military History, Faculty of Military Science, Stellenbosch University. This article is a reduction of a paper presented at the National University of Ireland (Maynooth) in 2011. I gratefully acknowledge financial assistance for the above-mentioned trip and research time at The National Archives, London, received through Prof IJ van der Waag from the NRF's Rated Researchers Incentive Programme. 
evaluated, with specific emphasis on changing patterns of leadership, command, and employment of the Division after Celleno.

Keywords: Union Defence Force, Italy, $6^{\text {th }}$ South African Armoured Division, $11^{\text {th }}$ South African Armoured Brigade, first battles, Celleno.

\section{Introduction}

The formation of the 6 SA Armd Div, in February 1943, had been shaped by the experience of the $1^{\text {st }}$ and $2^{\text {nd }}$ South African Infantry Divisions in the North African theatre. With some successes, but with possibly a greater number of defeats, the UDF's contribution to the war in North Africa remained wanting. ${ }^{2}$ The pace of warfare had indeed increased, and armoured warfare in essence negated the use of infantry in the vast expanses of the North African deserts. North Africa, as was successfully shown by Rommel's Afrika Korps, was tank country. As early as 1941, Major General G.E. Brink, then commander of 1 SA Division, tried to convince Field Marshal J.C. Smuts, the South African Prime Minister, and the Chief of General Staff, Lt Gen H.A. van Ryneveld, that the UDF infantry divisions should be reorganised into armoured divisions. Brink's argument rested on two solid foundations: firstly, armoured divisions would require less manpower than infantry divisions, thus freeing up valuable manpower needed by the South African war machine elsewhere; secondly, it remained futile to commit Springbok infantry against Axis armour ${ }^{3}$. Brink's argument was further bolstered by the fact that the UDF found it impossible to maintain three infantry divisions in the field. ${ }^{4}$ The necessity of converting to armour further stemmed from the South African quest to equip the UDF with modern fighting equipment. ${ }^{5}$

Brink had a strong supporter in Maj. Gen. F.H. (Frank) Theron, GOC SA Administrative Headquarters in Egypt, who strongly supported the decision to convert to armour. As early as 21 September 1941, Theron suggested that South African infantry brigades that were not occupied in battles should undergo conversion training into armoured formations. These troops, he felt, would subsequently form the nucleus of the future South African armoured formations. At a conference held in Gambut on 13 May 1942, Smuts informed the representatives of the UDF fighting units present that both South African divisions would undergo a conversion to armour. ${ }^{6}$ 
A decision was taken that South African troops should start attending courses at the Middle East Royal Armoured School by June 1942. Initially, only three UDF battalions would commence training in August, followed by another three in September. It was estimated that by December 1942 the first South African Armoured Brigade Group would be ready for actual deployment, followed by the second group by February 1943. ${ }^{7}$ The disaster at Tobruk during May-June 1942, when two South African Infantry Brigades were lost, and the subsequent route of the British $8^{\text {th }}$ Army from the Gazala Line, however, delayed the conversion to armour. ${ }^{8}$

On 1 February 1943, at a meeting at Defence Headquarters in Pretoria, the 6 SA Armd Div was officially formed and placed under the command of Major General W.H.E. Poole. ${ }^{9}$ The order of battle of the division included 11 SA Armoured Brigade, under command of Brigadier J.P.A. Furstenburg, and 12 SA Motorised Brigade under command of Brigadier R.J. Palmer, with the necessary divisional complements added to bolster the numbers of the division. ${ }^{10}$ By 8 February 1943, the units of the Division started to arrive at Zonderwater training centre where they underwent conversion to armour and motorised brigades. ${ }^{11}$ By March 1943, it was decided that the division would move to a staging area at Khataba, a desolate spot in the Egyptian desert. The Division would receive further armoured training at Khataba, where their equipment was already being assembled by early March. The Division received their armoured fighting vehicles from both the United States of America and Great Britain. The South African domestic war industry was unable to build tanks; however, armoured fighting vehicles such as the Marmon Herrington were produced locally. The Division, thus, made use of a myriad of British and American tanks, which included Crusaders, Grants, Shermans, Sextons, and Stuart Recce tanks. ${ }^{12}$ The Middle East GHQ Advisory Training Team for 6 SA Armd Div was under the impression that the division would be ready for service by the end of 1943. ${ }^{13}$ By 19 April 1943, the 6 SA Armd Div embarked for the Middle East, so as to start the desert phase of their training at Khataba. ${ }^{14}$

\section{Khataba: Armoured Training in the North African Desert}

By the end of January 1944, the 6 SA Armd Div moved to the transit camp at Helwan awaiting their deployment into the Italian theatre of operations. The Allied armies in Italy were numbering twenty divisions by January 
1944, whilst Field Marshall A. Kesselring's Army Group C numbered between twenty and twenty-one divisions. The British $8^{\text {th }}$ Army, in Italy very cosmopolitan in nature, did not want to burden themselves with the attachment of 6 SA Armd Div to their ranks. The Allied armies in Italy already had enough armoured divisions at their disposal, and it was felt that 6 SA Armd Div should rather remain behind in Palestine, where they could maintain law and order as garrison troops. The thought of being relinquished to mere garrison troops did not prove too popular with the South Africans, for it was not seen as a very glamorous posting. Even within the headquarters staff, doubts still existed as to the suitability of the 6 SA Armd Div for operational duty in Italy. Initially, the first South African armoured brigade group were to have been operationally deployable by midDecember 1942, but by the end of 1943, 6 SA Armd Div was still in Egypt awaiting actual deployment. Colonel E. Maggs, a member of the Divisional Staff, even felt that the Division was only adequately organised for fighting in the desert. Perhaps Maggs was simply stating the obvious. The complement of one armoured and one motorised brigade in an armoured division, according to Maggs, would prove unsuitable for deployment in the Italian theatre. Thus it would prove that only through the influence of Smuts, and his long-standing relationship with the British Prime Minister, Winston Churchill, would the 6 SA Armd Div go into battle in "Fortress Europe". ${ }^{15}$

The Division started to arrive at Khataba by May 1943, where members immediately attended courses at 6 SA Armd Div Training School. The 6 SA Armd Div Training School, established earlier during 1943, was not only responsible for the training of regimental and battalion instructors, but also presented courses for tank crew commanders, tank troop commanders, tank gunnery, tank driving, as well as tank maintenance. The instructors at the School, all graduates from the Middle East Royal Armoured School, ensured that the troops would be well versed in weaponry, eager for battle, and physically fit. The Divisional Headquarters insisted that the training received by their men, should guarantee the Division success on the battlefield. ${ }^{16}$ The period of training for the Division would last roughly eight months, meaning that the division would only have been operationally deployable by December 1943 . With the invasion of Sicily completed by August 1943, coupled with Mussolini's overthrow in July of the same year, the invasion of the Italian mainland became 
imminent. By September 1943, the British $8^{\text {th }}$ Army, and the US $5^{\text {th }}$ Army, invaded the Italian mainland. Upon return from the signing of the Italian Armistice, Theron paid a visit to the $8^{\text {th }}$ Army Headquarters in Sicily and once again the South African was urged to reconsider the conversion to armour, citing that the Division would be best employed as an infantry complement. This was not the first doubts that had been cast over the formation of 6 SA Armd Div. Theron knew that neither Smuts nor Van Ryneveld would succumb to pressure from the Allied authorities. ${ }^{17}$

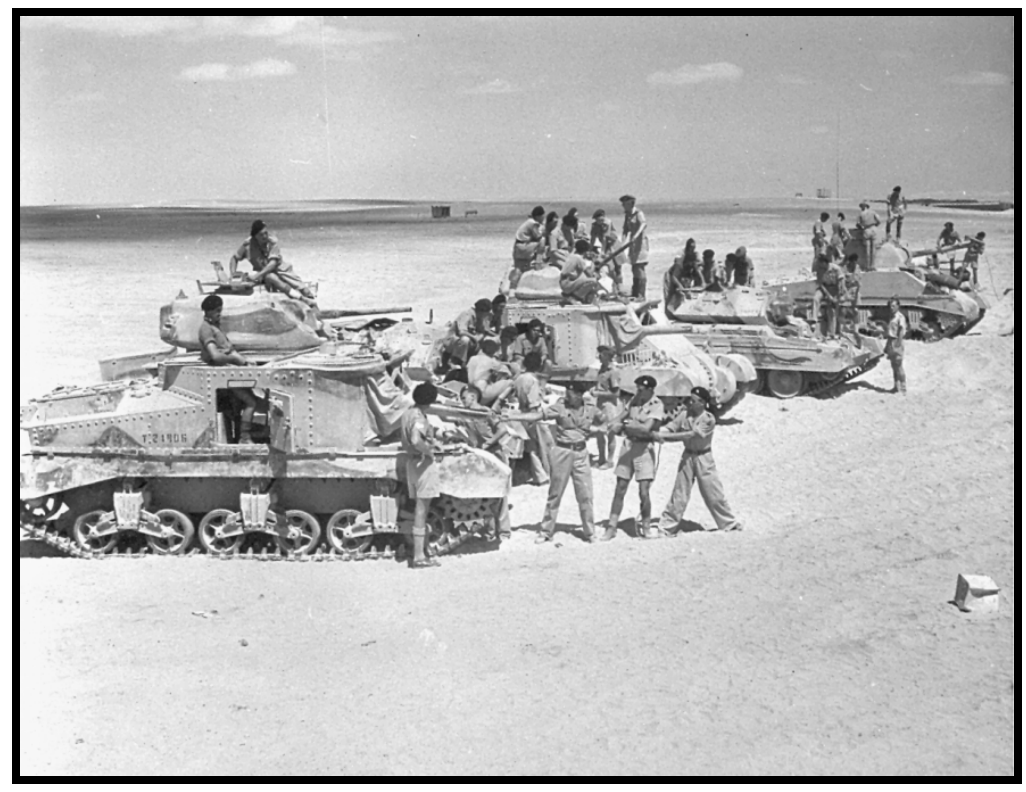

$6^{\text {th }}$ SA Armoured Division training in Egypt before leaving for Italy. ${ }^{18}$

The training that the men of the Division received at Khataba was of a far more specialised and difficult nature than training received within the Union, due to the peculiarities of armoured warfare. Within a week of their arrival, the men started receiving specialised training at Khataba. The armoured training the men received was unlike any training received by South African soldiers before. Specialised in nature, the training phase of the Division covered three broad aspects, namely basic training, unit training 
and formation training. ${ }^{19}$ During the basic training phase, the emphasis was placed on armour training. The individual thus received priority, in terms of qualifying the soldiers in the arts of gunnery, driving and maintenance as well as crew and troop commanders. Specialist training was first presented on an individual level, after which general training commenced so as to integrate the individual into the broader tank crew. During the unit training phase, training revolved around troop/platoon level up to and including regimental levels. The pace of training was directly affected by the availability and release of the specialised equipment which the Division required. The third and final phase of training was spent on honing the skills of combined armoured warfare. Formation training focused primarily on putting the brigades through their paces under the leadership of the divisional and respective brigade commanders. Formation training proved immensely valuable to Poole and his divisional staff, for it was the first instance in which they could test their skills in the application of the theory of combined warfare. ${ }^{20}$

During 1942, the UDF was already sensitised to the peculiarities of the combined arms approach in modern armoured warfare. A circular, which dealt with main lessons learned from operations in the Western Desert during 1942, was distributed amongst the senior UDF officers. Poole recognised that an armoured division should always operate as a complete entity. The armoured and motorised brigades should always deploy in close support of one another, so as to allow for closer cooperation on the battlefield. The motorised brigade would always have to retain its mobility, thus offering the division freedom of movement. This brigade in essence had to act in constant support of the armoured brigade. ${ }^{21}$

The men of 6 SA Armd Div furthermore learnt that, when an armoured attack commenced, anti-tank and artillery fire had to be used to halt the enemy forces effectively. The armoured brigades then had to use their tanks to either flank the enemy or complete an entire envelopment of the enemy forces concerned. Tanks furthermore only had to be used to engage enemy targets, such as tanks or enemy defensive positions, which had not been destroyed by the anti-tank or artillery fire. The armoured brigade's advance had to occur under mutual support offered by all armoured regiments taking part in the offensive action. The Divisional Staff further had to realise that the Division should never become committed to an 
extended fire fight with enemy tanks, due to the latter's overall superiority in firepower and armour. Thus, emphasis was placed on manoeuvre warfare and the constant exploitation of the enemies' unguarded flanks. Tanks had to be withdrawn from an engagement early enough, so as to reorganise and replenish for further offensive action. Mobility would thus remain the key to the future armoured actions of 6 SA Armd Div during their subsequent deployment in Italy. ${ }^{22}$

Initiative of individual commanders, such as Poole, Furstenburg and Palmer, would prove to be ever important in the light of the operations undertaken by 6 SA Armd Div. The maintenance of the initiative in battle would depend upon the timely committal of armoured and mobile forces in offensive roles. Maintenance of the initiative could only be achieved and sustained, if all available resources were committed and if the Division acted in unison. The rate of reorganisation and replenishment would have had a definite effect on the maintenance of the initiative in the field. Leadership of an armoured division in the field, and its offensive actions, would not only have tested the initiative of the divisional, brigade and regimental commanders, but also that of the squadron and troop commanders. ${ }^{23}$

The divisional training undertaken at Khataba, however, differed greatly from actual deployment in the Italian theatre of operations. Despite the emphasis of training being placed upon road movement, movement discipline, battle training and combined arms training, desert training essentially left the Division unprepared for deployment into the Italian theatre of operations, where the Division would operate in close country. The desert offered no opportunity for such training, due to the constant existence of the open flank in such terrain. ${ }^{24}$ In fact, the desert expanse of North Africa was most appropriate for armoured warfare, whereas Italy has been described as largely untankable. ${ }^{25}$ Khataba did, on the other hand, offer the Division ample space and time to hone their skills in armoured warfare. The desert conditions could, however, not prepare the men for the adverse weather conditions and topographical obstacles, which they would experience in Italy. ${ }^{26}$ The Italian peninsula was crisscrossed with rivers and mountain ridges, making armoured warfare and manoeuvring exceptionally difficult. Road and weather conditions, ranging from harsh winters to wet summers, severely hampered the movement of men to such an extent that 
modern equipment essentially slowed down the Allied advance across Italy. ${ }^{27}$

By the latter half of September 1943, General Sir H. Alexander, commander of the $15^{\text {th }}$ Army Group in Italy, made it clear that the Allied campaign in Italy would progress through four distinct phases. The first critical phase would include the consolidation of the Salerno-Bari line by the US $5^{\text {th }}$ Army and British $8^{\text {th }}$ Army. Secondly, the port of Naples would have to be secured, including the strategic airfield at Foggia. The third phase would include the capture of Rome and its vital military industrial and transport complex. The last phase would include a final push on Leghorn, Florence and Arezzo. Based on the above information, Poole and his Division felt almost certain that they would see action on the Italian mainland within a year. By November 1943, Field Marshal Kesselring took command of all the German forces in the Italian peninsula. Kesselring duly decided to remove all armoured divisions from the Italian theatre, and replace them with crack infantry divisions from the Russian front. ${ }^{28}$

The 6 SA Armd Div, still under training at Khataba, received a fresh batch of troops during September 1943. The lack of volunteers ${ }^{29}$ coming forward to sign the general service oath still badly affected the Division as a whole. During early October 1943, the UDF decided that under-strength units would be amalgamated so as to bring them up to battle strength. ${ }^{30}$ Coupled with the scheme of amalgamation, a liaison scheme was adopted between 6 SA Armd Div and the defunct 1 SA Armoured Division. ${ }^{31}$ The liaison scheme would operate on the premise that personnel from $1 \mathrm{SA}$ Armoured Brigade would be interchangeable with men from 11 SA Armoured Brigade. The interchange came into effect by October 1943, and would last up until January $1944 .^{32}$ The amalgamated units within the division now included the Imperial Light Horse/Kimberley Regiment (ILH/KimR), the First City/Cape Town Highlanders (FC/CTH), Witwatersrand/Regiment De la Rey (WR/DLR), $1 / 6^{\text {th }}$ Field Regiment, $4 / 22^{\text {nd }}$ Field Regiment, $7 / 23^{\text {rd }}$ Medical Regiment, $1 / 11^{\text {th }}$ Anti-Tank Regiment and the $1 / 12^{\text {th }}$ Light AA Regiment. ${ }^{33}$

The ranks of the 6 SA Armd Div were further bolstered by the arrival of a number of Rhodesian troops, which added a complement of artillery and armour. The ranks of the Division gradually began to swell and, by the 
end of 1943, started to resemble an operational armoured division. The Division included capable officers and men with experience dating back to the campaigns in Abyssinia, North Africa, and Madagascar. ${ }^{34}$ Despite the Division's numbers swelling, a distinct problem still existed in terms of a shortage of vehicles. ${ }^{35}$ By the beginning of October 1943, the Division only had 45 desert-worthy vehicles in its ranks. ${ }^{36}$ The training of the division was continuing, albeit at a slower pace than expected, due to the shortage of vehicles at its disposal. By the end of October things appeared to be changing for the better. The capture of Sicily had been completed, which in turn meant that more vehicles were assigned to the Division. By December 1943, before the commencement of the divisional exercises, 6 SA Armd Div was fully equipped with all the necessary complements of an armoured division. ${ }^{37}$

Van Ryneveld was in London during early November 1943. Once again the establishment and suitability of 6 SA Armd Div were brought into question. The argument centred on the fact that the British Army had more armoured divisions than what they required operationally. The Director of Military Training from the War Office, General J.A.C. Whittaker, argued that some of the British armoured divisions were being reorganised into infantry equivalents, and asked whether it would still be feasible and costeffective to establish a force like the 6 SA Armd Div. The matter was left unresolved, for Van Ryneveld's meeting in London could not generate any clarity on the question of conversion to armour. For the time being, the Division was to remain in Egypt and proceed with its desert training phase. As far as he was concerned, Smuts already vehemently expressed his desire that South Africa had to convert to armour. ${ }^{38}$

During February 1944, Poole and his Division received a report from a British armoured division with details of their experiences in the Italian theatre of operations. The report served as a tool through which the Division could adapt their tactical doctrine to the peculiarities of warfare on the European continent. The report indicated that sound leadership would prove the most influential in securing success for an armoured regiment during operational deployment in Italy. Apt leadership would also prevent unnecessary casualties from being incurred by the Division whilst deployed. The above argument stemmed from the fact that the topography of Italy was of such a nature that the leadership of individual troop commanders often 
decided the outcome of the battle. The terrain often prevented regimental and squadron commanders from keeping direct contact with their forward operating vehicles. The onus of quick decision-making was therefore often left to the junior officers on the frontlines. Thus, 6 SA Armd Div often operated on a decentralised chain of command. The decision-making abilities of the troop commanders on the ground, coupled with their individual determination and initiative, would remain the single impetus in the success of the entire armoured brigade. It was further appreciated that armoured regiments had four distinct disadvantages offered by the Italian topography, namely visibility, terrain, direction and physical obstacles. It was further mentioned that the only advantage which the armoured division could be afforded in Italy was that the area, which anti-tank guns could cover, was limited by the topography of the country. This meant that antitank weapons were often closely grouped together offering a prime target to the advancing armour and infantry. ${ }^{39}$

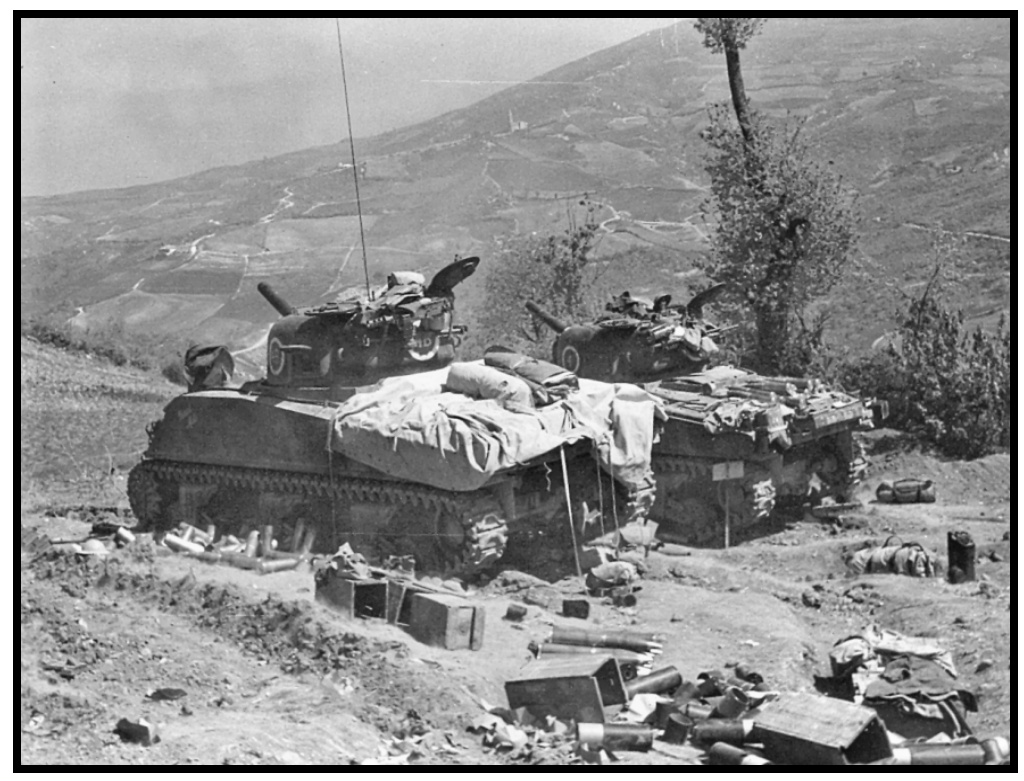

SA Sherman Tanks in Italy during World War II. ${ }^{40}$ 
The theoretical knowledge of handling an armoured division was further improved by notes compiled by a South African officer who had served in Italy with the $1^{\text {st }}$ Royal Tank Regiment. These notes were circulated amongst the officers and men of the Division. Of utmost importance here was the valuable insight gained by Poole and his men as to the precise role which an armoured regiment plays in an armour division during offensive operations. Poole and his divisional staff thus became aware that an armoured brigade only acts in four ways. Firstly, the armoured brigade always acts as the spearhead of the advance. Secondly, armoured brigades could act as a screen for the withdrawal of troops. Thirdly, an armoured brigade could be used as assault troops against enemy armoured troops. Lastly, an armoured brigade can occupy holding positions and defend against all types of enemy assault. The assault on Celleno would subsequently confirm these principles. ${ }^{41}$

By December 1943, the 6 SA Armd Div training cycle in the desert neared completion. The South Africans embarked on brigade manoeuvres in the desert so as to test their battle worthiness. During the period 1-3 December 1943, 11 SA Armoured Brigade partook in Exercise Cape Town with their attached troops, whilst 5-7 December saw 12 SA Motorised Brigade participating in Exercise Durban. The first round of the desert exercises ended in success for the two brigades, and their respective brigadiers, in terms of battle handling in armoured warfare. Towards the end of December, the Armoured Brigade took part in another divisional exercise, Exercise Zonderwater. During January 1944, the Division as a whole took part in Exercise Tussle, upon instruction from General Headquarters Middle East. Tussle was to be the Division's first experience of operating alongside another division, under conditions of simulated warfare. Tussle occurred under the auspices of the British III Corps, and involved 6 SA Armd Div and a British armoured division "fighting" against an enemy comprising of the $1^{\text {st }}$ and $4^{\text {th }}$ Egyptian Infantry Brigades, $2^{\text {nd }}$ Belgian Infantry Brigade, $11^{\text {th }}$ Indian Infantry Brigade, and the $10^{\text {th }}$ Armoured Division. The aim of the exercise was to test all of the headquarters, from divisional to company/squadron level, in command and control of the division in battle. ${ }^{42}$ The exercise further included aspects such as gapping minefields, passing through an armoured brigade, and the planning and control of the movement of the division in "restricted" space. The exercise was a resounding success, albeit extremely tough, and 
culminating in a great armoured "battle" in the desert. The completion of Tussle signalled the end of the desert training cycle of the division. Smuts addressed the division on 8 December, and promised them that they would definitely be in the thick of action once the hour of victory arrived. He left them with the words, "Julle sal daar wees!" ("You will be there"). ${ }^{43}$ In March 1944, the decision was taken to move 6 SA Armd Div to Italy, so as to assume offensive operations under the British $8^{\text {th }}$ Army. The South African move to the Italian theatre took everyone by surprise.

\section{The Battle of Celleno - 10 June 1944}

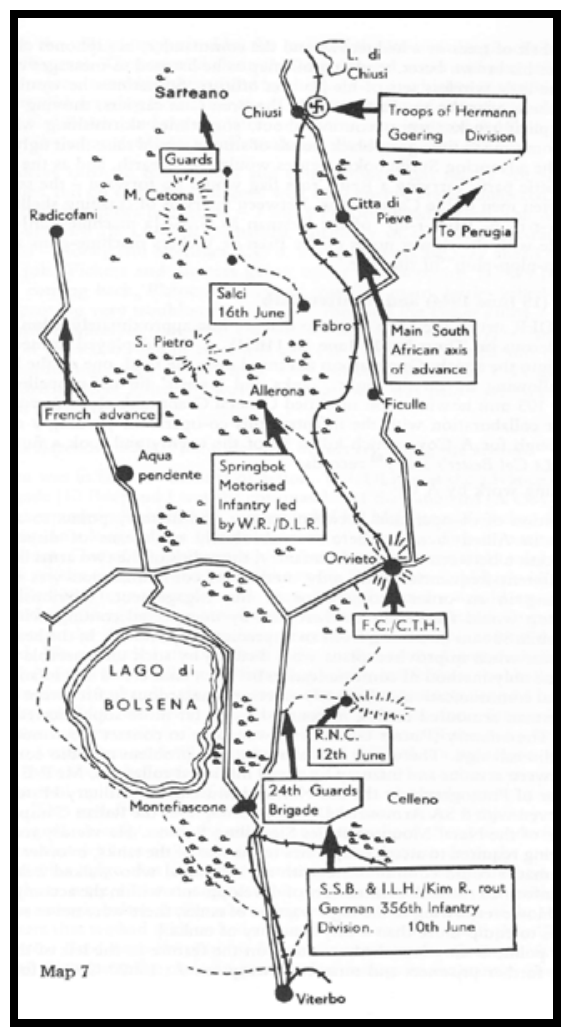

The Advance towards Florence. ${ }^{44}$ 
Towards the end of March 1944, the transit arrangements for 6 SA Armd Div started to fall into place. The South African divisional and brigade commanders made one last effort to try and recruit personnel to act as reinforcements for the Division, but elements within the UDF still did not want to sign the general service oath. ${ }^{45}$ By 16 April 1944 most of the Division had embarked for Italy, and units started to arrive on the mainland from 20 April onwards. The South African Division quickly organised for battle, and British $8^{\text {th }}$ Army HQ decided to send 12 SA Motorised Brigade into the Allied lines facing Cassino. The Brigade was to relieve the $11^{\text {th }}$ Canadian Infantry Brigade of the static defensive line which it occupied, after which it was part of the general advance north. ${ }^{46}$

On 6 June 1944, lead elements of the 6 SA Armd Div started passing through Rome. The pursuit through Rome northwards was entrusted to the US $5^{\text {th }}$ Army and the British $8^{\text {th }}$ Army. The 6 SA Armd Div fell under the direct command of XIII Corps of the British $8^{\text {th }}$ Army, which was entrusted with the pursuit northwards along the river Tiber. The two armoured divisions of the British $8^{\text {th }}$ Army - South African and British - would advance northwards in unison. ${ }^{47}$ The 6 SA Armd Div had as its final objective the liberation of Florence, a mere 290 kilometres by road. ${ }^{48}$ The 11 SA Armoured Brigade would act as the armoured spearhead for the entire advance northwards. ${ }^{49}$

The advance northwards was mostly unopposed during 6 June 1944, with the leading elements of the Division penetrating up to 50 kilometres north of Rome. The speed of 11 SA Armoured Brigade's advance proved extraordinary, when taking into account that the brigade comprised of 1050 vehicles moving in a single column northwards. Some German resistance was met; however, these actions proved to be part of a bigger series of delaying actions fought by the German forces. As the Division neared Civita Castellana on 7 June 1944, German resistance began to stiffen. Intelligence reports indicated that the Germans were covering their withdrawal to a series of prepared defensive positions running up the spine of the Italian mainland. The German withdrawal coincided with planned demolitions of vital bridges on the Tiber River, which meant that 6 SA Armd Div had to shift its axis of advance so as to counter the loss of vital bridgeheads across the Tiber. ${ }^{50}$ 
On the morning of 8 June 1944, Poole was informed that it would be impossible for 6 SA Armd Div to cross the river Tiber. Once again the Division's axis of advance had to be redirected. The South Africans now had to continue their vanguard duties west of the Tiber, to capture Fabrica and Vallerano, and then to swing their axis of advance to the west so as to capture Viterbo, Montefiascone, Orvieto, Allerona, Chiusi, and eventually Florence (see map). ${ }^{51}$ The South African contingent received priority on the Fabrica-Vallerano road, despite the Division encroaching on the American sector of operations. The South Africans continued their advance on Vallerano, with the tanks of the Natal Mounted Rifles (NMR) and Special Service Battalion (SSB) leading the advance, throughout which 11 SA Armoured Brigade continued to meet stiffer resistance as it advanced up the road towards Viterbo. ${ }^{52}$ The 6 SA Armd Div was opposed by the $356^{\text {th }}$ German Infantry Division. The $356^{\text {th }}$ Division, essentially inexperienced and raw, was bolstered by the support of the $4^{\text {th }}$ Parachute Division, which included elements of the $3^{\text {rd }}$ Panzer Grenadiers and units of the $362^{\text {nd }}$ Infantry Division. It was thus not surprising that the German resistance stiffened considerably, for some elements of the division were comprised of experienced troops who had seen action throughout the war. ${ }^{53}$

By 9 June 1944, the South African forces had captured Vallerano, Canepina, and the all-important town of Viterbo. Alexander confirmed that 6 SA Armd Div would remain the spearhead of the Allied advance towards Florence. On 10 June 1944, the South Africans deployed their entire Armoured Brigade in the advance towards Florence. This would prove the first and also last opportunity during the entire Italian campaign in which the entire Armoured Brigade could be deployed in unison. In a daring move, Poole deployed his armoured brigade without the necessary support from the Divisional artillery. Furstenburg realised that the $356^{\text {th }}$ German Infantry Division would withdraw northwards. The German opposition encountered, comprised of the $356^{\text {th }}$ Division's left flank. Furstenburg's intention was to turn the German left flank by ordering the SSB to advance on the right flank. $^{54}$

The advance on the German right flank started at first light on the morning of 10 June 1944. The ILH/KimR and SSB immediately moved forward to establish contact with the German defensive line north of the town of Aqua Rossa. The advance north was intended to secure the 
bridgehead around Aqua Rossa, but the South African advance was soon halted by heavy enemy mortar fire. The NMR, acting as divisional reconnaissance, moved forward early in the morning to scout the enemy dispositions around Aqua Rossa. The NMR almost immediately drew heavy fire from the German anti-tank screen, losing two tanks early in the morning. The SSB was immediately ordered forward to come to the rescue of the NMR. ${ }^{55}$ The SSB advanced barely a single kilometre along the road when they met stiff enemy resistance in the form of heavy machine gun and anti-tank fire. As soon as the SSB formed up for the attack, they received heavy enemy shellfire. ${ }^{56}$ Having committed to the attack without the necessary divisional artillery support, the leading elements of the brigade were now in a rather perilous position. Lt. Col. C.E.G. ("Papa”) Brits, the officer commanding of SSB, decided to advance against the enemy in a twoup formation, with his 'A' Squadron forming a fire support base on the high ground whilst the other two squadrons advanced further forward. Under the covering fire from the SSB tanks, the NMR was able to extricate themselves from danger. ${ }^{57}$

The advance northwards proved extremely tough on the tanks of 11 SA Armoured Brigade. At one stage, the Brigade could count on one tank being knocked out for every 16 kilometres advanced. The advance also proved taxing on the men of the Brigade. In one instance, the NMR had one personnel casualty for every $2 \frac{1}{2}$ kilometres advanced. ${ }^{58}$ The Italian theatre, topographically, also proved a further stumbling block to the men of $11 \mathrm{SA}$ Armoured Brigade. The staff of the Division soon realised that there was a definite difference between physical and tactical mobility. The South Africans incrementally came to understand that in modern combat, their infantry complement often remained more relevant than their tanks, owing to the nature of the war in Italy. The battle of Celleno further reinforced this notion. Adverse weather conditions could abruptly change the conditions on the ground, often rendering farm tracks impassable to the tanks of the brigade. ${ }^{59}$ Movements along the roads of Italy proved even more difficult for the divisional staff, thus often resulting in traffic jams that that made it difficult for the formation to be in the right place at the right time. ${ }^{60}$

Under the cover of the firm base established by two troops of ' $A$ ' Squadron SSB, the rest of the squadron was ordered forward into hull-down positions. Brits' gamble paid off, for as soon as the tanks started to lay 
down sufficient suppressive fire on the enemy, they broke their ranks. The left flank of the German defences, defended by a brigade, almost immediately collapsed, and the enemy infantry was routed. The two squadrons, acting in unison, were able to silence the enemy defensive screen which had weapons ranging from 20 millimetres to 88 millimetres. The enemy guns were silenced by the superb marksmanship of the South African and Rhodesian gunners. ${ }^{61}$ The ILH/KimR accompanied the advance of the SSB, with some infantry going into action on the back off the advancing tanks. Brits committed all of his tanks into action, except for his own tank. Following rapid replenishment from the rear, the SSB were once again ready to move on to the offensive. Whilst replenishment was underway, forward observation officers of the divisional artillery were able to move forward and link up with the lead elements of the SSB. The ILH/KimR proceeded to secure the area from enemy pockets of resistance. ${ }^{62}$

By midday, 10 June 1944, the Divisional artillery started engaging the numerous enemy targets in and around Aqua Rossa and the town of Celleno. Within two hours from commencing the artillery barrage, the divisional artillery could account for the destruction of five 88-mm guns, sixteen 50mm anti-tank guns, three machine-guns, one Mark IV tank, four Mark III tanks, and numerous infantry. ${ }^{63}$ Under cover of the artillery barrage, two companies of ILH/KimR joined ranks with the SSB on their advance to Celleno village. 'A' Company ILH/KimR continued to clear the slopes leading up to the village of Celleno. The clearing of the enemy's prepared defensive positions was only possible through close cooperation between the tanks of SSB and the infantry of ILH/KimR. ${ }^{64}$ The area that was cleared, a thickly wooded one, was used by the $356^{\text {th }}$ Division to conceal a myriad of machine-gun nests and Panzerfaust anti-tank guns. To silence the German guns effectively, a slow and dangerous process, the infantry dismounted from the tanks so as keep up the momentum of the attack. Brits realised that he had to keep his tanks moving forward towards the vicinity of Celleno, where the approaches were obstructed by a railway embankment which ran right across the South African axis of advance. The only way to negotiate the obstacle was by means of a small road which ran beneath the railway line. The German troops had a series of prepared defensive positions along this road, which made the advance rather dangerous. The German opposition included anti-tank guns, and infantry armed with Panzerfausts, Spandaus, and sniper rifles. ${ }^{65}$ 
' $C$ ' Squadron of the SSB managed to break through the German defensive line along the road passing underneath the railway line. The tanks immediately advanced further up the road, and moved into a hull-down position on high ground. The tanks automatically reverted to act as a direct fire support base for the advancing infantry from ILH/KimR. The tanks were now in essence acting as artillery, and started to bring down accurate fire on the village of Celleno. Under cover of the fire brought down on the Celleno, the infantry was able to clear the area of any remnants of the $356^{\text {th }}$ Division from their defensive positions around the village. Enemy resistance, however, remained ever-present, and 'A' Squadron SSB suffered a number of losses. Offensive action by ' $\mathrm{C}$ ' Squadron SSB, allowed men of ILH/KimR to advance towards the village. 'B' Squadron SSB now turned their advance to the high ground immediately north of Celleno. ${ }^{66}$ Having managed to move one troop of ' $\mathrm{B}$ ' Squadron onto the high ground, Furstenburg ordered ' $\mathrm{C}$ ' Squadron into an area on the right of the village which had to be cleared. 'A' Squadron and reconnaissance tanks of the SSB, moved the infantry of ILH/KimR further forward, and then successfully dealt with enemy resistance on the right of the village. The mopping up operations of the ILH/KimR quickly developed into a full-scale attack on the town of Celleno. The three squadrons of the SSB were now all moved onto high ground surrounding the village, and from there the tanks could hold the ground and provide sufficient fire support to the advancing infantry. The infantry quickly moved through the town, clearing the enemy resistance out house by house. ${ }^{67}$

The Battle of Celleno, fought over twelve hours, was effectively over by sunset, with 11 SA Armoured Brigade emerging as the victors. The Brigade could account for a vast number of prisoners being taken, as well as heavy casualties being inflicted on the enemy's $356^{\text {th }}$ Division. ${ }^{68}$ By the evening of 10 June, Furstenburg ordered Brits to halt his advance. Enemy fire had died down, and the tanks of the SSB had exhausted all of their ammunition and petrol. Brits' advance could not continue due to the divisional artillery first having to move forward. Poole ordered Furstenberg to hold the ground, and the SSB tanks subsequently withdrew to an area 3 kilometres to the south of Celleno from where they could rest and replenish their tanks. ${ }^{69}$ The $24^{\text {th }}$ Guards Brigade would resume the advance on the morning of 11 June, and continue the route of the German $356^{\text {th }}$ Division. ${ }^{70}$ During the day's action in and around the town of Celleno, the Prince 
Alfred's Guard (PAG) was ordered by Furstenburg to cover the SSB's right flank. Having moved out of Viterbo, the tanks started meeting immense enemy resistance as they neared Grotte Santo Stefano. Without adequate infantry support, the advance was halted early in the morning. ${ }^{71}$ The Pretoria Regiment (PR), operating under command of the $24^{\text {th }}$ Guards Brigade, was ordered to move forward at around dawn to provide $11 \mathrm{SA}$ Armoured Brigade with fire support around the area of Celleno-Grotte Santo Stefano. The tanks of PR immediately moved into turret-down positions, and continued to ravage the countryside with over 1200 rounds of highexplosive throughout the day. ${ }^{72}$

Making do with few available resources, the men of the Brigade were able to overcome all odds and secure the relief of Celleno. ${ }^{73}$ Poole believed that his tactical headquarters always had to be deployed as close as possible to the frontlines. This often allowed him the freedom of movement and the ability to keep up to date on developments on his immediate front. ${ }^{74}$ The Divisional Headquarters' protective troop of tanks was always available for rapid deployment so as to secure or bolster any part of the divisional front. Poole's belief that he had to be close to the action further offered him the chance to take quick decisions based on first-hand knowledge gained from his Brigadiers on the ground. Where the presence of a divisional commander in the forward operational areas might have been a burden on the brigade commanders, such presence also served as inspiration to the soldiers on the ground. ${ }^{75}$

During the day's events at Celleno, Poole wanted to see for himself how 11 SA Armoured Brigade was coping with their first armoured battle. Poole was aware that success at the Battle of Celleno would have an immense effect on the morale of his Division for the remainder of the campaign. He furthermore realised that his whole division would learn valuable lessons from the experience gained. Consequently, Poole and his command tank moved forward towards the action taking place around Celleno. ${ }^{76}$ Furstenburg's tactical headquarters was deployed in the van with the lead elements of the SSB during the attack on Celleno. Poole decided to move to Furstenburg's position. Furstenburg and Brits were, however, too occupied with the battle to pay any attention to their divisional commander peering over their shoulders. In essence, neither of the two men had time for discussion with Poole at that particular moment. With Poole's arrival 
imminent, Furstenburg lashed out at the divisional staff for bringing Poole under close enemy fire. He argued that Poole's presence in the forward areas just added to the current burden of the Brigade, which was critically busy at that moment. The divisional staff was eventually able to persuade Poole to withdraw. Poole knew that he did not have to look over the shoulders of his brigade and regimental commanders during battle. He did, however, feel that he personally needed to keep updated with the events occurring at the frontlines. For the remainder of the campaign in Italy, Poole insisted that his tactical headquarters always remain in close proximity to the advancing Brigade. When that was not possible, he would often advance with just his command tank and a small party of staff officers. ${ }^{77}$

The battle of Celleno culminated as South Africa's first victory in the Italian campaign. The Brigade, having lost only 14 men killed and 38 wounded, was able to inflict over 200 casualties on the opposing German forces. ${ }^{78}$ A year prior to the battle, however, the Division was still training in the desert expanses of Khataba. Under-equipped, under-strength, and unsure of their future, the 6 SA Armd Div was able to turn themselves into a capable, armoured, fighting force within less than a year.

\section{After Celleno: Lessons Learned, Lessons Applied}

The lessons learned by 6 SA Armd Div, and most notably by 11 SA Armoured Brigade, during the Battle of Celleno had an immense effect on the latter's operations during the Division's campaign in Italy. Actual deployment in Italy, and the Battle of Celleno, had highlighted the shortcomings of the entire Division. The lessons learned by the Division varied, although the lessons learned during training in the desert of North Africa still applied. The leadership of the Division, in particular the brigade and regimental commanders, proved to be the most influential in adapting the South African notion of armoured warfare as was learned during the time spent at Khataba. ${ }^{79}$

Williamson Murray, in Military innovation in the interwar period (1998), states that innovation remained ever important to armies that are constrained by doctrinal rigidity. He further argues that military institutions are known to show contempt to feedback that ultimately contradicts 
institutionalised doctrine and conceptions of warfare. It was an unavoidable conclusion that the high command of armies always had all the answers, and that there was no need, nor the time, to extract lessons from operations. The British Army during the Second World War served as a prime example of this and so it was left to each division to innovate on its own on the battlefield. Tactical innovation was, therefore, only developed on the battlefield, arguably the most expensive and dangerous, place from which to learn. ${ }^{80}$ The 6 SA Armd Div, however, had to adapt quickly and they had to innovate, for their training in the desert had not prepared them adequately for armoured operations in Italy. The leadership of the Division proved to be the single most important factor that influenced tactical innovation on the battlefield. The varied experiences of the divisional, brigade, regimental, squadron and company, troop and platoon commanders in battle, directly influenced the pace and scope of innovation within the division. ${ }^{81}$

Tactical innovation, as adopted by 6 SA Armd Div after their baptism of fire at Celleno, centred on changes in command, organisation, the specific roles of infantry and armour, rest and recuperation and identifying specific enemy methods used during offensive operations. ${ }^{82}$ The relationship between armour and infantry, whilst fighting on the battlefield, received the most attention in terms of innovation. It was ascertained that only after the infantry and armour understood one another's role completely, could they cooperate successfully. ${ }^{83}$ This in turn eliminated the drawbacks which the Division initially experienced. Decisions and appreciations by Poole, Furstenburg and Palmer, had to be rapid, so as to engage the enemy immediately. When armour was held up, the infantry component passed through their ranks and continued the advance. When the armour of the Division engaged anti-tank weapons, the infantry immediately moved up and secured the ground. ${ }^{84}$ This allowed the armour to withdraw on immediate contact, and thus offered the infantry the time and space to manoeuvre their forces adequately on the battlefield. Infantry and armour cooperation only succeeded when sufficient radio communication existed between the different groupings. Good communication ensured unity of force and facilitated the combined arms approach to which the 6 SA Armd Div was striving. ${ }^{85}$

In terms of command and control, the Division learned that the proper dissemination of information remained a key to success on the battlefield. 
The squadrons and companies of the Division operated best when their regimental and brigade commanders were updated with all relevant information regarding the stance of offensive operations. ${ }^{86}$ If a lack of information ever occurred, the advancing troops would often be left uncertain of the positions that were occupied by divisional and flanking formations. The speed and security of the Division's advance bore direct resemblance to the availability of real-time information, and this directly prevented Allied units from engaging one another. ${ }^{87}$

Experience gained whilst on offensive operations, helped the men of the Division to identify with, and distinguish between, different enemy tactics employed whilst fighting in Italy:

- When the Division encountered obstacles along their advance it was always registered as an artillery target by the enemy forces. When they halted too long at such an obstacle, often marked by a white board, the enemy always brought down an immense barrage of artillery fire.

- The enemy always occupied houses or high ground, and used these as forward observation posts.

- Enemy anti-tank weapons were always covered by infantry. The infantry always withdrew, so luring the Division's armour forward into the anti-tank killing fields.

- Infantry anti-tank weapons, such as bazookas, were more often than not only used whilst the enemy was on the defensive.

- Enemy sniping was always deadly accurate. Enemy snipers were often difficult to locate and so proved a nightmare for tank commanders who were always left vulnerable in their tanks.

- Enemy demolitions of vital infrastructure were common, albeit not always very effective. Areas around the enemy demolitions were often mined, and were therefore always to be approached with care. 
- The enemy infantry remained very effective, but chose not to engage the tanks of the Division on their own. Enemy infantry always withdrew to defensive lines, which were well-protected by self-propelled and anti-tank guns.

- Enemy tanks only engaged the Division's tanks from long range; they never appeared willing for a tank on tank engagement.

- The enemy made ample use of the Italian countryside for his offensive and defensive operations. It was, however, felt that the German troops in Italy did not fight with the ferocity of their counterparts in Africa.

The Division, taking the above-mentioned into account, soon learned how to counter the enemy and his methods effectively during offensive operations. $^{88}$

The Division learned that armoured warfare could prove very taxing on the mind, body, soul and equipment. It was soon realised that, for the equivalent of two days' work, the men of the Division would need one day's rest. Depending on the needs of the Division, the men could be forced to act operationally for longer periods. However, due to the taxing nature of armoured warfare and the physical demands of tanks, men in an armoured division needed ample time for rest, recuperation and maintenance. ${ }^{89}$ Poole also realised that the artillery forward observation officers needed to be right in the front of his Division's advance, so as to secure ready fire support from the divisional artillery. The immediate relaying of information to the divisional artillery, could mean instant death to the enemy. Furthermore, Poole and his Brigade Commanders soon realised that 1:50 000 topographical maps were inadequate for armoured warfare. In mobile operations, the 1:50 000 maps would suffice, but 1:25 000 maps proved much better in battle. The 1:25 000 maps were indeed more accurate and they could accurately show the relief of the country. It thus became a prerequisite to have detailed maps in the Division. ${ }^{90}$

The Division also learned that dust meant death. The slightest disturbance of the road surface by fast-moving tracked or wheeled vehicles alerted the enemy to the Division's movements and brought down a sudden 
barrage of enemy artillery fire. ${ }^{91}$ Poole further appreciated the fact that his entire Division had to be in good radio contact with one another, especially his own channels up to higher command. A problem that was experienced was the interference on radio networks by commercial broadcasting stations. The interference would also often come at the most inconvenient time, and sometimes Poole lost all communications with his forward operating echelons due to civilian radio activity on their network. ${ }^{92}$ Poole and his staff realised that an adequate tank-training facility had to be established at their reserve squadron. This tank-training facility would ensure that untrained troops did not get sent forward to fighting units. ${ }^{93}$

\section{The Remainder of the Italian Campaign}

After the attack on Celleno, 6 SA Armd Div continued their advance on Florence, better honed for fighting in Italy. Through Cetona and Chiusi, the South Africans continued to meet stiff resistance from the Herman Goering Division. By 4 August 1944, 6 SA Armd Div was one of the first units to enter Florence and thus to secure for themselves a well-earned rest. After a mandatory period of rest, recuperation and refitting, the 6 SA Armd Div was ready to continue its offensive operations in Italy. At this stage, however, the 6 SA Armd Div was placed under command of the US $5^{\text {th }}$ Army, under command of General Mark Clark. Under American command, the 6 SA Armd Div continued the advance northwards towards the Apennines. The Gothic Line was reached and breached fairly easily before the onset of the European winter. The German resistance stiffened considerably during the Allied advance north, with the enemy successfully fighting a series of delaying actions as they retreated north through a series of successive defensive lines. ${ }^{94}$ The Italian winter and geography would prove to be the single biggest obstacle for the South African armoured division, with some troops even undergoing conversion courses at the School of Mountain Warfare during December $1944 .{ }^{95}$

By September 1944, the Division had helped to liberate the town of Castiglione dei Pepoli, after which Monte Stanco was taken on 14 October 1944. The fighting conditions in the Apennines were unlike any experienced by South African soldiers during the entire war. The campaign during the winter became static, with the weather and geographical conditions ruling out any armoured operations. The fighting was left to the 
infantry, with the 12 SA Motorised Brigade bearing the brunt of the fighting through Florence up until the German surrender in 1945. This included occupying Monte Sole, Monte Caprara, and eventually crossing the river Po. The Division was able to adapt to these peculiar difficulties quite adequately. Through sheer determination and ingenuity, 6 SA Armd Div overcame the challenges of the Italian geography: mountains, rivers, marshes, mud, rain and snow. The work of the South African engineer units also helped to ease the advance of the Division through the difficult Italian terrain. The combined arms approach ultimately ensured that the Division was able to make a difference in the Italian campaign. In all earnest, artillery learned to provide fire support for the entire Division, armour learned to provide mutual support to the infantry, and infantry learned that they had to work in unison with armour so as to assault enemy positions effectively. But the fighting units of the Division also came to appreciate that without the tireless work of the divisional support units, their success in offensive operations would have been nil. ${ }^{96}$

Celleno remained the only battle of the Italian campaign during which the entire 11 SA Armoured Brigade fought as a complete entity. Furthermore, Celleno proved to be the Division's only real tank battle, despite hardly engaging any enemy tanks head-on. During the rest of the campaign, the armoured regiments often acted as independent entities on the battlefield. ${ }^{97}$ With the advance into the Apennines, large-scale mobile operations by the armoured brigade became impossible and the fighting, in essence, became an infantry affair, with tanks being relegated to the position where they would merely act as a direct or indirect fire support base in support of the advancing infantry. ${ }^{98}$ It seems as if Maggs' opinion and doubts about the future employment of the Division, ultimately became a reality. Apart from the fact that the allied armies in Italy already had too many armoured divisions at their disposal, and that 6 SA Armd Div was more of a burden to them than a blessing, the Division only successfully fought a handful of clearly distinguishable armoured battles. As such, the composition of 6 SA Armd Div remained wanting. The Division was indeed better equipped for armoured operations in the desert, and a motorised division, with a small armour attachment, would clearly have been better suited for deployment in Italy. The $1^{\text {st }}$ and $2^{\text {nd }}$ South African Infantry Divisions should in fact have been reorganised into a motorised division and sent to the Italian theatre, whilst 6 SA Armd Div would have 
been a viable addition to the Allied forces fighting Rommel in North Africa. ${ }^{99}$ Nevertheless, the Division successfully completed its allotted tasks up to the cessation of hostilities in Italy on 2 May 1945. The war in Italy, was over for the South Africans. ${ }^{100}$

During Poole's address at the Division's victory parade held at Monza, he highlighted certain successes of the Division's Italian campaign:

The campaign is an epic. You forcing the so-called impregnable GHENGHIS KHAN line by the capture of the almost unscalable MONTE SOLE, CAPRARA, and ABELE positions ... the defeat of the crack $1^{\text {st }}$ and $4^{\text {th }}$ Para Divisions rearguards from SAN GIOVANI to FINALE ... and overrunning the Hun by the thousand up to the River BRENTA ... all these have added a new and glorious page to military history and to the honour of South Africa. ${ }^{101}$

\section{Conclusion}

The Battle of Celleno, 10 June 1944, was in essence the first, and the only real tank battle fought by 11 SA Armoured Brigade during the Italian campaign. Having emerged from the battle with flying colours, the Division continued in earnest with offensive operations in the Italian theatre until the cessation of hostilities in May 1945. The success of the armoured brigade at the Battle of Celleno conferred upon the division a high degree of selfconfidence and boosted the entire division's morale. The Battle of Celleno proved to be the only instance during the entire Italian campaign of 6 SA Armd Div where the entire armoured brigade could act in unison during an offensive operation. During the rest of the campaign, the Motorised Brigade bore the brunt of the actual fighting, with small, independent, armoured actions often being fought by the individual armoured regiments.

The UDF, and more notably 6 SA Armd Div, went through an intensive cycle of innovation during the Second World War. This was clearly shown by the fact that the UDF possessed hardly any armoured forces at the outbreak of the war, but emerged from it with one of the biggest allied armoured divisions at the cessation of hostilities. The UDF emerged from the Second World War with modern fighting equipment, and a vast array of experience gained by the men who saw action through East Africa, Madagascar, North Africa and in Italy. Post-war geo-political 
positioning, meant that South Africa was able to offer its military services during the Korean War, and subsequently in the abortive Africa Defence Organisation and Middle East Defence Organisation. The next time South African armour would be called into action would be in Angola, approximately 30 years after the end of the Second World War.

CE Heller \& WA Stofft (eds). America's first battles 1776-1965. Lawrence, KS: University Press of Kansas, 1986, ix-xiii.

J Bourhill. Come back to Portofino: Through Italy with the $6^{\text {th }}$ South African Armoured Division. Johannesburg: 30 Degrees South, 2011, 7983, 31.

J Kros. War in Italy: With the South Africans from Taranto to the Alps. Rivonia: Ashanti, 1992, 1-5; Bourhill op. cit., pp. 31-35.

JSM Simpson. South Africa fights. London: Hodder \& Stoughton, 1941, 99-104.

Public Record Office (PRO). WO/06/4931 M.O.2B Collation, S/A 12, South Africa Intelligence (Misc) October 1941 - July 1945. Reuters extracts covering the formation of the $6^{\text {th }}$ South African Armoured Division.

South African Department of Defence Documentation Centre (DOC C). CGS War, Box 173, Conversion to Armoured Division, Memorandum on Organisation of SA Armoured Division 21 November 1942.

N Orpen. South African forces World War II (Vol V): Victory in Italy. Cape Town: Purnell, 1975, 1-2.

DOC C. CGS War, Box 6, SA Armoured Corps 2/8, CGS Armoured Corps Conference 25 March 1943.

DOC C. UWH Civil, Box 143, NAREP CMF 4, 6 SA Armoured Division 25 March 1944.

DOC C. CGS War, Box 6, SA Armoured Corps 2/8, CGS Armoured Corps Conference 25 March 1943; DOC C. UWH Civil, Box 143, NAREP CMF 4, 6 SA Armoured Division 25 March 1944.

Bourhill op. cit., pp. 31-36.

Published by Authority. A record of the organisation of the DirectorGeneral of War Supplies 1939-1943 and Director-General of Supplies 1943-1945. Pretoria: Government Printers, s.a., 53, 68; W Marshall. Camouflage and markings of the $6^{\text {th }}$ South African Armoured Division: North Africa \& Italy 1943-1945. Warsaw: Model Centrum Progress, 2010. Orpen op. cit., pp. 4-6.

Ibid., p. 7.

Ibid., pp. 22-24.

DOC C. Union War Histories (UWH) Civil, Box 140, NAREP CMF 1, Trg History of 6 SA Armoured Division (E. Axelson April 1944).

Orpen op. cit., pp. 8-11.

DOC C. Photo Collection, 781005467, $6^{\text {th }}$ SA Armoured Division training in Egypt before leaving for Italy. Grant Sherman and Crusader tanks busy with training in North Africa, 1943. 
DOC C. UWH Civil, Box 143, NAREP CMF 4, 6 SA Armoured Division (28 March 1944).

DOC C. UWH Civil, Box 140, NAREP CMF 1, Trg History of 6 SA Armoured Division (E. Axelson April 1944).

DOC C. Chief of the General Staff (CGS), Group 2, Box 651, G 1019/106/1 Training memoranda AFV, Lessons learned in the desert: Training memorandum no. 7/1942.

Ibid.

Ibid.

DOC C. UWH Civil, Box 140, NAREP CMF 1, Trg History of 6 SA Armoured Division (E. Axelson April 1944).

JF MacDonald. The war history of Southern Rhodesia (Vol II). Rhodesia: Rhodesian Government Printers, 1950, 589; JFC Fuller. On future warfare. London: Sifton Praed, 1928, 284.

DOC C. CGS War, Box 73, Gen. Poole's divisional correspondence, Poole's liaison letter with CGS, Liaison letter no. 13 dated 25 January 1944; Bourhill op. cit., pp. 79-83.

A Jacobs \& H Smit. "Topographic mapping support in the South African Military during the $20^{\text {th }}$ century”. Scientia Militaria 32/1. 2004. 33, 43-45.

A Bryant. The turn of the tide. London: Collins, 1957, 716-717, 723-727; Orpen op. cit., pp. 12-13.

The South African soldiers initially signed the Africa Service Oath, which allowed them to serve anywhere on the African continent. As the Second World War continued into 1943, the prospect of South African troops having to serve in theatres outside of Africa became a reality. The UDF thus introduced a new oath, the General Service Oath, which soldiers could sign voluntarily and thus commit themselves to serve anywhere in the world. Some elements within the UDF however decided not to sign the oath for a number of reasons. See Simpson op. cit., pp. 88-104.

Bourhill op. cit., p. 36.

The $1^{\text {st }}$ and $7^{\text {th }}$ SA Infantry Brigades would have been reorganised into $1^{\text {st }}$ SA Armoured Division; however, after the disaster at Tobruk during May to June 1942, this scheme had to be dropped. The UDF would also find it impossible to maintain two operational armoured divisions in the field, and it was hence decided to only form one armoured division, 6 SA Armoured Division.

Orpen op. cit., pp. 13-15; DOC C. CGS War, Box 6, SA Armoured Corps 2/8, CGS Armoured Corps Conference 25 March 1943.

DOC C. CGS War, Box 73, Gen. Poole's divisional correspondence, Poole's liaison letter with CGS, Liaison letter no. 13 dated 9 May 1944.

PRO. Cabinet Papers (CAB)/106/644, AL 708, History of $6^{\text {th }}$ SA Armoured Division in Italy October 1942 - May 1945.

Bourhill op. cit., pp. 35-36; PRO. WO/216/243, E 1627, BM 29/1961, File no. 13, Cypher from MIDEAST to FREEDOM concerning the shortage of 'B' vehicles for 6 SA Armoured Division, February 1943.

An armour regiment normally comprised of a minimum of 55 tanks. 
Orpen op. cit., pp. 16-17; W Otto. S.D.B/S.S.B.:1933-1973. Pretoria: Staatsdrukker, 1973, 87-90.

Orpen op. cit., p. 17; Bryant op. cit., p. 440.

DOC C. Divisional documents (DIV DOCS) 6 Division, Group 1, Box 174, Lesson from ops, An Armoured Regiment Report on Ops in Italy.

DOC C. Photo collection, 700009986, SA Sherman tanks in Italy during World War II.

DOC C. CGS, Group 2, Box 651, G 1019/106/1 Training memorandum AFV, Training memorandum no. 10/43.

DOC C. CGS War, Box 73, Gen. Poole's divisional correspondence, Poole's liaison letter with CGS, Liaison letter no. 13 dated 25 January 1944; Bourhill op. cit., p. 79.

Orpen op. cit., pp. 20-21; Bourhill op. cit., pp. 75-76.

S Monick. A bugle calls: The story of the Witwatersrand Rifles and its predecessors 1899-1987. Johannesburg: Witwatersrand Rifles Regimental Council, 1989, 353.

Simpson op. cit., pp. 88-104.

Orpen op. cit., pp. 23-25.

Ibid., pp. 50-53.

PRO. CAB/106/644, AL 708, History of $6^{\text {th }}$ SA Armoured Division in Italy October 1942 - May 1945; PRO. War Office (WO)/216/168, E 1625, Leese Dos to Kennedy, file no. 29A, Personal correspondence between Lt. Gen. Sir Oliver Leese, C-in-C Eight Army, and Maj. Gen. John Kennedy, ACIGS (Ops) concerning the allied offensive in Italy, 10 July 1944.

Orpen op. cit., pp. 50-53; DOC C. Narratives and reports (NAREP), CMF 2, 5871-5958, The Sixth South African Armoured Division in Italy (history recording section), 29-36.

DOC C. NAREP, CMF 2, 5871-5958, The Sixth South African Armoured Division in Italy (history recording section), 29-36.

N Orpen. Prince Alfred's Guard: 1856-1966. Cape Town: Cape and Transvaal Printers, 1967, 203.

Orpen, Victory in Italy op. cit., pp. 59-65.

Ibid., pp. 59-65; DOC C. UWH Civil, NAREP CMF 1, Box 140, SSB regimental history, June 1944.

Orpen, Victory in Italy op. cit., pp. 64-65; Orpen, Prince Alfred's Guard op. cit., p. 203.

DOC C. UWH Civil, Box 140, NAREP CMF 1, SSB regimental history, June 1944.

DOC C. World War 2 War Diaries (WW2 WD), Box 601, 11 SA Armoured Brigade War Diary, Special Service Battalion War Diary, June 1944.

Orpen, Victory in Italy op. cit., pp. 65-66; DOC C. WW2 WD, Box 601,11 SA Armoured Brigade War Diary, Headquarters 11 SA Armoured Brigade War Diary, June 1944.

E Goetzsche. Rough but ready: An official history of the Natal Mounted Rifles and its antecedent and associated units 1854-1969. Durban: Privately Published, 1973, 319. 
JA English. A perspective on infantry. New York: Praeger, 1981, 173-175. Orpen, Victory in Italy op. cit., pp. 63-64.

DOC C. WW2 WD, Box 601, 11 SA Armoured Brigade War Diary, Special Service Battalion War Diary, June 1944. The Rhodesian complement of 6 SA Armoured Division included three armoured squadrons, an anti-tank and artillery complement.

Orpen, Victory in Italy op. cit., p. 66.

Bourhill op. cit., pp. 144-147.

DOC C. WW2 WD, Box 601, 11 SA Armoured Brigade War Diary, Headquarters 11 SA Armoured Brigade War Diary, June 1944.

Orpen, Victory in Italy op. cit., pp. 66-67.

DOC C. WW2 WD, Box 601, 11 SA Armoured Brigade War Diary, Headquarters 11 SA Armoured Brigade War Diary, June 1944.

Orpen, Victory in Italy, op. cit., pp. 67-68.

PRO. CAB/106/644, AL 708, History of $6^{\text {th }}$ SA Armoured Division in Italy October 1942 - May 1945.

DOC C. WW2 WD, Box 601, 11 SA Armoured Brigade War Diary, Headquarters 11 SA Armoured Brigade War Diary, June 1944.

Orpen, Victory in Italy op. cit., pp. 68-69.

DOC C. WW2 WD, Box 638, PAG WD, Prince Alfred's Guards War Diary, June 1944.

DOC C. WW2 WD, Box 640, PR (PAO) WD, Pretoria Regiment (Princess Alice's' Own) War Diary, June 1944.

Bourhill op. cit., pp. 144-147.

PRO. CAB/106/644, AL 708, History of $6^{\text {th }}$ SA Armoured Division in Italy October 1942 - May 1945.

Orpen, Victory in Italy op. cit., pp. 55-56.

PRO. CAB/106/644, AL 708, History of $6^{\text {th }}$ SA Armoured Division in Italy October 1942 - May 1945.

Orpen, Victory in Italy op. cit., pp. 65-69.

DOC C. NAREP, CMF 2, 5829-5870, The story of South Africa's Sixth

Armoured Division; Bourhill op. cit., pp. 144-147.

Bourhill op. cit., pp. 144-147; Goetzsche op. cit., p. 313.

W Murray. "Patterns of military innovation in the interwar period". In W Murray \& AR Millet (eds), Military innovation in the interwar period, Cambridge: Cambridge University Press, 1998, 322-324.

Goetzsche op. cit., p. 313.

Fuller op. cit., p. 127.

PRO. CAB/106/733, AL 1195, Notes on armour operations, File 156: Operations. Notes on the forces required to break the Rimi-Pisa Line, 16 June 1944; Fuller op. cit., pp. 292-301.

English op. cit., pp. 173-175.

K Macksey. Tank warfare. London: Granada, 1971, 245; H Strachan. European armies and the conduct of war. London: Routledge, 1993, 185.

Fuller op. cit., p. 292.

Goetzsche op. cit., p. 314.

Ibid., pp. 315-316. 
RM Ogorkiewicz. Armoured forces. London: Arms and Armour Press, 1970, 44-45.

Jacobs \& Smit op. cit., pp. 43-45; Goetzsche op. cit., pp. 315-318; PRO. $\mathrm{CAB} / 106 / 733$, AL 1195, Notes on armour operations, File 156: Operations. Notes on the forces required to break the Rimi-Pisa Line, 16 June 1944.

Goetzsche op. cit., pp. 319-320.

Macksey op. cit., pp. 249-250.

Goetzsche op. cit., pp. 319-320.

DOC C. UWH Civil, Box 143, NAREP CMF 4, Italian Campaign: The story of the Sixth by Lt. Armstrong, 12 March 1945.

Bourhill op. cit., p. 344.

DOC C. UWH Civil, Box 143, NAREP CMF 4, Italian Campaign: The story of the Sixth by Lt. Armstrong, 12 March 1945; PRO. CAB/106/733, AL 1195, Notes on armour operations, File 156: Operations. Notes on the forces required to break the Rimi-Pisa Line, 16 June 1944.

Macksey op. cit., p. 219.

MacDonald op. cit., p. 589; PRO. CAB/106/733, AL 1195, Notes on armour operations, File 156: Operations. Notes on the forces required to break the Rimi-Pisa Line, 16 June 1944.

Orpen, Victory in Italy op. cit., pp. 22-24; Marshall op. cit., pp. 5-6.

Bourhill op. cit., pp. 424-425.

DOC C. UWH Civil, Box 349, Special orders of the day July 1944 - May 1945, Poole's address at the 6 SA Armoured Division Victory Parade. 